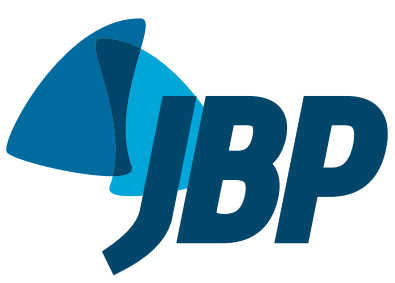

\section{Eliminating tuberculosis in Latin America: making it the point}

\author{
Raquel Duarte 1,2,3,a, Denise Rossato Silva ${ }^{4, \mathrm{~b}}$, Adrian Rendon ${ }^{5, \mathrm{c}}$, \\ Tatiana Galvẫo Alves ${ }^{6, \mathrm{~d}}$, Marcelo Fouad Rabahi ${ }^{7, \mathrm{e}}$, Rosella Centis ${ }^{8, \mathrm{f}}$, \\ Afrânio Kritski ${ }^{9,9}$, Giovanni Battista Migliori ${ }^{8, h}$
}

In 2015, the World Health Organization (WHO) launched the End TB strategy, which has three pillars-integrated, patient-centered care and prevention; bold policies and supportive systems; and intensified research and innovation-and has the inbuilt concept of the elimination of tuberculosis. ${ }^{(1-4)}$ The elimination of tuberculosis has been defined as $<1$ case per million population, preelimination having been defined as $<10$ cases per million. Since then, the three pillars have been officially adopted by a number of countries ${ }^{(5)}$ : in 2015, by Brazil, Ethiopia, the Russian Federation, South Africa, and Vietnam; and in 2016, by India, Indonesia, Swaziland, and Thailand.

Following a joint WHO/European Respiratory Society (ERS) consultation with countries with a low incidence of tuberculosis (< 10 cases per 100,000 population), held in Rome in 2014, the WHO launched its Framework Towards Tuberculosis Elimination In Low-Incidence Countries. ${ }^{(1)}$ The document identified eight major areas to be tackled in order to eliminate tuberculosis in such countries. ${ }^{(1)}$

In epidemiological terms, tuberculosis control strategies focus on the early identification and effective treatment of cases of infectious tuberculosis (to break the chain of transmission and reduce the incidence); tuberculosis elimination is an additional strategy which has at its core the identification of latently infected individuals and their treatment (to sterilize the "reservoir" of infected persons and ensure future generations of infection-free individuals $),(1,6,7)$ investing today to prevent tuberculosis cases tomorrow. ${ }^{(1,6,7)}$ There is evidence that, when applied consistently, the tuberculosis elimination strategy has been effective. For example, it has been reported to have reduced the incidence of tuberculosis by up to $17 \%$ per year in Inuit populations. ${ }^{(8)}$

An initial question to be answered is whether there have been any reports of experiences with the tuberculosis elimination strategy in high-burden countries. Recent studies conducted in the countries of Cyprus and Oman have shown that the appropriate implementation of the basic elements of the End TB strategy can drive the epidemiology of tuberculosis toward the pre-elimination threshold. ${ }^{(9,10)}$ A second question is to what extent the tuberculosis elimination strategy can be applied in Latin America and the Caribbean, where there are a number of low-incidence countries-including the Bahamas, Chile, Costa Rica, Cuba, the Dominican Republic, Jamaica, and Puerto Rico, as well as Trinidad and Tobago-and others that are approaching that threshold-including Brazil, Uruguay, and Colombia-those in the latter category also having been invited to the WHO/ERS technical consultation in Rome in 2014.

In parallel with the publication of the WHO framework, ${ }^{(1)}$ the Pan American Health Organization (PAHO) created two important documents. In 2015, the organization issued a document including all three pillars of the End TB strategy, the PAHO Strategic Plan, (11) which followed its Action Plan for the Prevention and Control of Tuberculosis. Launched in 2013, the PAHO action plan focused on tuberculosis control only, using epidemiological indicators (i.e., increased numbers of patients with bacteriologically confirmed tuberculosis that was treated successfully), promoting cross-cutting approaches in health, and covering comorbidities (e.g., HIV infection and mental health disorders). ${ }^{(12)}$ Those documents were followed by the Roadmap for Tuberculosis Elimination in Latin America and the Caribbean, created jointly by the ERS and the Asociación Latinoamericana del Tórax (ALAT, Latin-American Thoracic Society), to guide national tuberculosis programs toward implementation of the PAHO strategies. It is clear that there is considerable heterogeneity in Latin America in terms of epidemiological actions and programs, the strategic goals mentioned above therefore being met at different paces. ${ }^{(3,4)}$ One example is provided by the epidemiology of tuberculosis in Mexico (Figure 1), where the reported incidence of the disease is below the low-incidence threshold in one third of the states, < 20 per 100,000 population in another third, and higher than that in the remaining third.

In 2017, the Brazilian National Ministry of Health issued a document aimed at the elimination of tuberculosis, the National Plan to End Tuberculosis as a Public Health Problem. The plan was designed with the goal of reducing tuberculosis incidence (to $<10$ cases/100,000 population)

1. Serviço de Pneumologia, Centro Hospitalar de Vila Nova de Gaia-Espinho, Porto, Portugal

2. Epidemiology Research Unit - EpiUNIT - Instituto de Saúde Pública, Universidade do Porto, Portugal.

3. Faculdade de Medicina, Universidade do Porto, Porto, Portugal.

4. Faculdade de Medicina, Universidade Federal do Rio Grande do Sul - UFRGS - Porto Alegre (RS) Brasil.

5. Centro de Investigación, Prevención y Tratamiento de Infecciones Respiratorias, Hospital Universitario, Universidad Autonoma de Nuevo Leon, Monterrey, México.

6. Serviço de Pneumologia, Hospital Especializado Octávio Mangabeira, Secretaria de Saúde do Estado da Bahia, Salvador (BA) Brasil.

7. Faculdade de Medicina, Universidade Federal de Goiás - UFG - Goiânia (GO) Brasil.

8. WHO Collaborating Centre for TB and Lung Diseases, Fondazione Salvatore Maugeri, Istituto di Ricovero e Cura a Carattere Scientifico - IRCCS - Tradate, Italia.

9. Programa Acadêmico de Tuberculose, Hospital Universitário Clementino Fraga Filho - HUCFF - Instituto de Doenças do Tórax - IDT - Faculdade de Medicina, Universidade Federal do Rio de Janeiro, Rio de Janeiro (RJ) Brasil.

a. (iD) http://orcid.org/0000-0003-2257-3099; b. (iD) http://orcid.org/0000-0003-0230-2734; c. (iD) http://orcid.org/0000-0001-8973-4024;

d. (iD) http://orcid.org/0000-0002-3038-7715; e. (iD) http://orcid.org/0000-0002-4050-5906; f. (iD) http://orcid.org/0000-0002-8551-3598;

g. (iD http://orcid.org/0000-0002-5900-6007; h. (iD http://orcid.org/0000-0002-2597-574X 

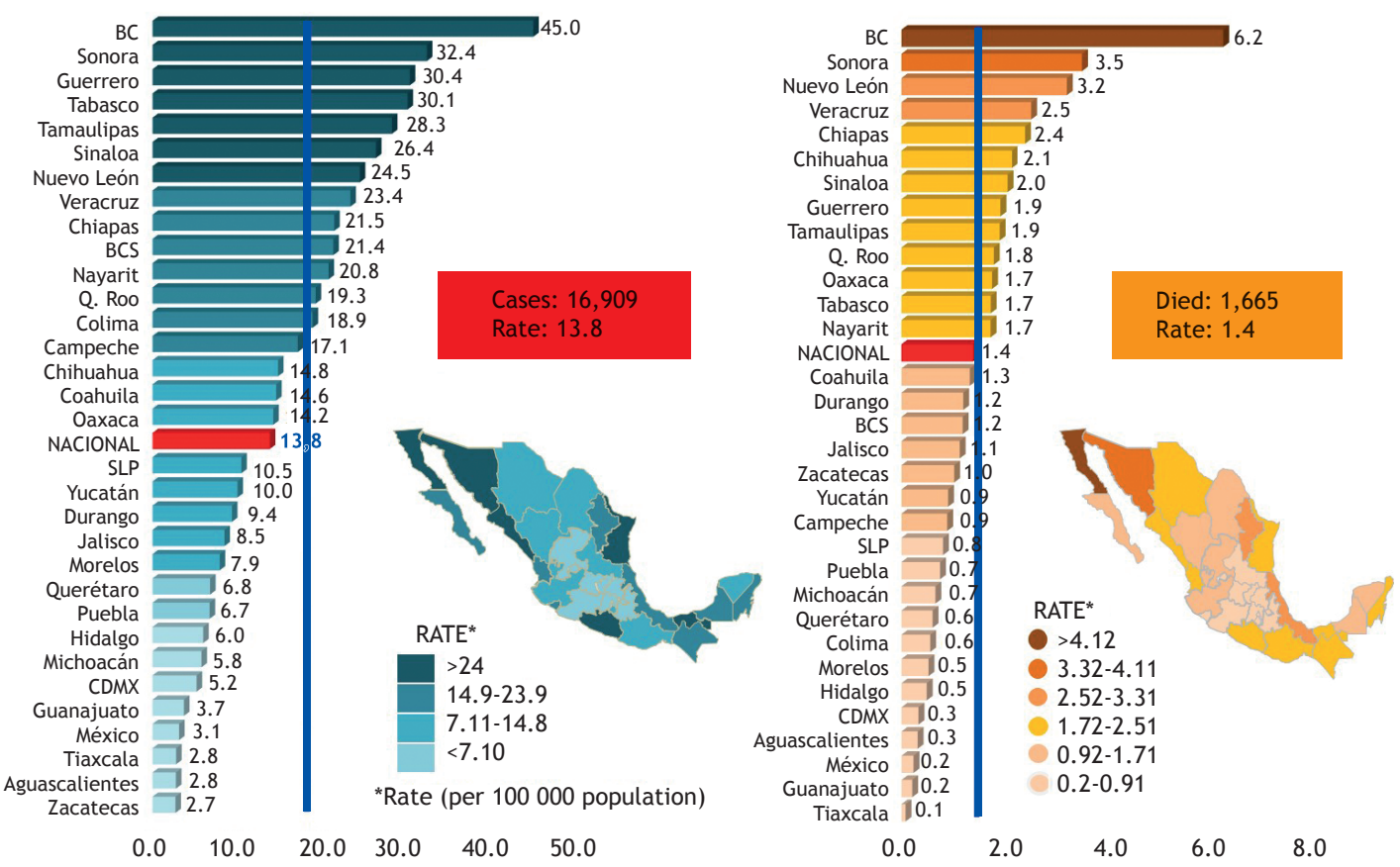

Figure 1. Incidence of reported cases of pulmonary tuberculosis and associated mortality in Mexico (per 100,000 population in 2016 and 2015, respectively), by state. Obtained from the Mexican Ministry of Health.

and mortality (to $<1$ death/100,000 population) by 2035, defining the approaches to implementing each of the three pillars of the WHO End TB strategy. ${ }^{(13)}$

In Latin America, visible progress has been made toward meeting the goals set for tuberculosis incidence, prevalence, and mortality. ${ }^{(3,4)}$ Among the remarkable successes achieved are increased detection rates, improved laboratory quality assurance, better systematic management of cases of multidrug-resistant tuberculosis (MDR-TB), and the promotion of community involvement, as well as coordination of technical and financial partners. ${ }^{(3,4)}$

Although there has been a decrease in the reported number of new cases in Brazil, that decrease has been modest (only $1.5 \%$ per year) and more needs to be done to improve treatment outcomes, reduce losses to follow-up, and prevent the emergence of MDR-TB. (14) Clearly, there is a need for political commitment (with adequate funding and legal framework), true patient-centered care, and attention to comorbidities, as well as the control of risk factors such as diabetes, HIV infection, illicit drug use, smoking, and mental disorders. ${ }^{(15)}$ Special attention should also be given to vulnerable groups (e.g., migrants from rural areas to large cities, south-south migrants (i.e., migrants between developing countries), people living in slums, underserved indigenous populations, homeless individuals, and prisoners). ${ }^{(16)}$

The eight core areas identified in the ERS/ALAT Roadmap for Tuberculosis Elimination in Latin America and the Caribbean provide a clear guide to reaching the tuberculosis elimination targets in the region:

1. identifying and supporting vulnerable populations
2. addressing migration and transborder issues

3. strengthening operational research, channeling it through agreed-upon national research plans prioritized by national tuberculosis research networks and adequately funded to tackle the intensified research/innovation pillar of the End TB strategy

4. fostering political commitment for tuberculosis care and prevention in order to implement elements of the bold policies/supportive systems pillar of the End TB strategy

5. adapting the strategy at the national and regional level while promoting global collaboration

6. enhancing active detection and treatment of latent tuberculosis infection, as well as active tuberculosis, according to the principles of tuberculosis elimination $(5,17)$

7. ensuring early, high-quality treatment of cases of drug-resistant tuberculosis and MDR-TB while ensuring universal drug-susceptibility testing with conventional and/or new molecular methods and availability of the necessary second-line drugs (in order to tackle, with core area 1, the actions included in the integrated, patient-centered care/ prevention pillar of the End TB strategy

8. improving continuous surveillance, monitoring, and evaluating activities to assess the progress toward the planned targets and the elimination of tuberculosis

Indicators for the monitoring and evaluation of each of those components were also proposed (Table 1$).^{(3,4)}$

The contribution of tuberculosis research networks, as proposed by the WHO in 2015 , is key to working in accordance with regional priorities. ${ }^{(18)}$ The joint ERS/ ALAT/Brazilian Thoracic Society tuberculosis project and the Brazilian Tuberculosis Research Network are 
Table 1. Indicators of the impact and implementation of the World Health Organization End TB strategy for LatinAmerican and Caribbean countries.

\begin{tabular}{|c|c|c|c|c|}
\hline \multirow[t]{2}{*}{ Impact indicators } & \multicolumn{2}{|c|}{ Milestones } & \multicolumn{2}{|c|}{ Targets } \\
\hline & 2020 & 2025 & $2030^{a}$ & $2035^{b}$ \\
\hline Reduction in number of TB deaths compared with 2015 & $35 \%$ & $75 \%$ & $90 \%$ & $95 \%$ \\
\hline Reduction in TB incidence rate compared with 2015 & $20 \%$ & $50 \%$ & $80 \%$ & $90 \%$ \\
\hline Families facing catastrophic costs due to TB & $0 \%$ & $0 \%$ & $0 \%$ & $0 \%$ \\
\hline Implementation indicators & \multicolumn{4}{|c|}{ Recommended target level } \\
\hline TB treatment coverage & \multicolumn{4}{|c|}{$\geq 90 \%$} \\
\hline TB treatment success rate & \multicolumn{4}{|c|}{$\geq 90 \%$} \\
\hline Households that experience catastrophic costs due to TB & \multicolumn{4}{|c|}{$0 \%$} \\
\hline Newly reported TB cases diagnosed using WHO recommended rapid tests & \multicolumn{4}{|c|}{$\geq 90 \%$} \\
\hline Latent TB infection treatment coverage & \multicolumn{4}{|c|}{$\geq 90 \%$} \\
\hline Contact investigation coverage & \multicolumn{4}{|c|}{$\geq 90 \%$} \\
\hline Drug susceptibility coverage for TB patients & \multicolumn{4}{|c|}{$100 \%$} \\
\hline Treatment coverage, new TB drugs & \multicolumn{4}{|c|}{$\geq 90 \%$} \\
\hline Documentation of HIV status among TB patients & \multicolumn{4}{|c|}{$\geq 90 \%$} \\
\hline Case fatality ratio & \multicolumn{4}{|c|}{$\leq 5 \%$} \\
\hline Availability of the planned budget for TB & \multicolumn{4}{|c|}{$100 \%$} \\
\hline Implementation of planned monitoring and evaluation activities & \multicolumn{4}{|c|}{$100 \%$} \\
\hline
\end{tabular}

TB: tuberculosis; and WHO: World Health Organization. aSustainable development goals. ${ }^{b}$ World Health Organization End TB strategy targets.

making significant contributions by generating the evidence necessary for successful implementation of the tuberculosis elimination strategy. ${ }^{(19)}$ Some of the preliminary results are quite encouraging, ${ }^{(20-35)}$ showing how important it is to implement all three pillars of the WHO End TB strategy in Latin America.

\section{REFERENCES}

1. Lönnroth K, Migliori GB, Abubakar I, D’Ambrosio L, de Vries G, Diel $R$, et al. Towards tuberculosis elimination: an action framework for low-incidence countries. Eur Respir J. 2015;45(4):928-52. https://doi. org/10.1183/09031936.00214014

2. D'Ambrosio L, Dara M, Tadolini M, Centis R, Sotgiu G, van der Werf MJ, et al. Tuberculosis elimination: theory and practice in Europe. Eur Respir J. 2014:43(5):1410-20. https://doi. org/10.1183/09031936.00198813

3. Rendon A, Fuentes Z, Torres-Duque CA, Granado MD, Victoria $J$, Duarte $R$, et al. Roadmap for tuberculosis elimination in Latin American and Caribbean countries: a strategic alliance. Eur Respir J. 2016;48(5):1282-1287. https://doi.org/10.1183/13993003.015492016

4. Torres-Duque CA, Fuentes Alcalá ZM, Rendón A, Migliori GB. Roadmap for Tuberculosis Elimination in Latin America and the Caribbean. Arch Bronconeumol. 2018;54(1):7-9. https://doi. org/10.1016/j.arbres.2017.07.004

5. World Health Organization [homepage on the Internet]. Geneva: World Health Organization; c2017 [cited 2017 Nov 27]. Globa tuberculosis report 2017; [about 2 screens]. Available from: http:// www.who.int/tb/publications/global_report/en/

6. de Vries G, van Hest $R$, Bakker M, Erkens $C$, van den Hof $S$, Meijer $W$, et al. Policy and practice of programmatic management of latent tuberculosis infection in The Netherlands. J Clin Tuberc Other Mycobact Dis. 2017;7:40-48. https://doi.org/10.1016/j. jctube.2017.02.002

7. Veen J, Migliori GB, Raviglione MC, Rieder HL, Dara M, Falzon D, et al. Harmonization of TB control in the WHO European Region: the history of the Wolfheze Workshops. Eur Respir J. 2011;37(4):950-9. https://doi.org/10.1183/09031936.00019410

8. Grzybowski S, Styblo K, Dorken E. Tuberculosis in Eskimos. Tubercle. 1976;57(4 Suppl):S1-58. https://doi.org/10.1016/00413879(76)90059-3

9. Voniatis C, Migliori GB, Voniatis M, Georgiou A, D'Ambrosio $L$, Centis $R$, et al. Tuberculosis elimination: dream or reality? The case of Cyprus. Eur Respir J. 2014;44(2):543-6. https://doi. org/10.1183/09031936.00044314

10. Al Yaquobi F, Al-Abri S, Al-Abri B, Al-Abaidani I, Al-Jardani A,
D'Ambrosio L, et al. TB elimination, dream or reality? The case of Oman. Eur Respir J. 2018:51(1). pii: 1702027. https://doi. org/10.1183/13993003.02027-2017

11. Pan American Health Organization [homepage on the Internet] Washington (DC): the Organization; [cited 2017 Nov 27]. Plan of Action for the Prevention and Control of Tuberculosis. [Adobe Acrobat document, 24p.]. Available from: http://www.paho.org/hq/ index.php?option=com_docman\&task=doc_view\&gid=31254\&ltem id $=270 \&$ lang $=$ en

12. Pan American Health Organization [homepage on the Internet] Washington (DC): the Organization; [cited 2014 Nov 20]. Strategic Plan of the Pan American Health Organization 2014-2019. [Adobe Acrobat document, 147p.]. Available from: http://www.paho.org/hq/ index.php?gid=14004\&option=com_docman\&task=doc_view

13. Brasil. Ministério da Saúde [homepage on the Internet]. Brasilia: Ministério; c2017 [cited 2017 Nov 27]. Brasil livre da tuberculose - Plano nacional pelo fim da tuberculose como problema de saúde pública. 1st edition. [Adobe Acrobat document, 40p.]. Available from: http://portalarquivos.saude.gov.br/images/pdf/2017/fevereiro/24/ Plano-Nacional-Tuberculose.pdf

14. Rabahi MF, Silva Júnior JLRD, Conde MB. Evaluation of the impact that the changes in tuberculosis treatment implemented in Brazil in 2009 have had on disease control in the country. J Bras Pneumol. 2017;43(6):437-444. https://doi.org/10.1590/s180637562017000000004

15. Migliori GB, Lienhardt C, Weyer K, van der Werf MJ, Blasi F, Raviglione MC. Ensuring rational introduction and responsible use of new TB tools. Outcome of an ERS multisector consultation. Eur Respir J. 2014;44(6):1412-7. https://doi.org/10.1183/09031936.00132114

16. Pareek M, Greenaway C, Noori T, Munoz J, Zenner D. The impact of migration on tuberculosis epidemiology and control in high-income countries: a review. BMC Med. 2016;14:48. https://doi.org/10.1186/ s12916-016-0595-5

17. Getahun H, Matteelli A, Abubakar I, Aziz MA, Baddeley A, Barreira D et al. Management of latent Mycobacterium tuberculosis infection: WHO guidelines for low tuberculosis burden countries. Eur Respir J 2015;46(6):1563-76. https://doi.org/10.1183/13993003.01245-2015

18. World Health Organization [homepage on the Internet]. Geneva: 
World Health Organization; c2015 [cited 2017 Nov 24]. A global action framework for TB research in support of the third pillar of WHO's end TB strategy; [about 2 screens]. Available from: http:// www.who.int/tb/publications/global-framework-research/en/

19. Kritski A, Barreira D, Junqueira-Kipnis AP, Moraes MO, Campos MM, Degrave WM, et al. Brazilian Response to Global End TB Strategy: The National Tuberculosis Research Agenda. Rev Soc Bras Med Trop. 2016;49(1):135-45. https://doi.org/10.1590/0037-8682-03302015

20. Arbex MA, Siqueira HR, D'Ambrosio L, Migliori GB. The challenge of managing extensively drug-resistant tuberculosis at a referral hospital in the state of São Paulo, Brazil: a report of three cases. J Bras Pneumol. 2015;41(6):554-9. https://doi.org/10.1590/s180637562015000000299

21. Dalcolmo M, Gayoso R, Sotgiu G, D'Ambrosio L, Rocha JL, Borga $L$, et al. Effectiveness and safety of clofazimine in multidrugresistant tuberculosis: a nationwide report from Brazil. Eur Respir J 2017;49(3). pii: 1602445. https://doi.org/10.1183/13993003.02445 2016

22. Silva DR, Sotgiu G, D'Ambrosio L, Pereira GR, Barbosa MS, Dias NJD, et al. Diagnostic performances of the Xpert MTB/RIF in Brazil. Resp Med. 2018;134:12-15. https://doi.org/10.1016/j.rmed.2017.11.012

23. Amicosante M, D'Ambrosio L, Munoz MA, Mello FCQ, Tebruegge $\mathrm{M}$, Chegou NN, et al. Current use and acceptability of nove diagnostic tests for active tuberculosis: a worldwide survey. J Bras Pneumol. 2017 Sep-Oct;43(5):380-392. https://doi.org/10.1590/ s1806-37562017000000219

24. Rendon A, Centis R, D'Ambrosio L, Migliori GB. WHO strategies for the management of drug-resistant tuberculosis. Arch Bronconeumol. 2017:53(3):95-97. https://doi.org/10.1016/j.arbres.2016.07.015

25. Muñoz-Torrico M, Caminero-Luna J, Migliori GB, D'Ambrosio L, Carrillo-Alduenda JL, Villareal-Velarde $\mathrm{H}$, et al. Diabetes is Associated with Severe Adverse Events in Multidrug-Resistant Tuberculosis Arch Bronconeumol. 2017;53(5):245-250. https://doi.org/10.1016/j. arbr.2016.10.003

26. Muñoz-Torrico M, Caminero Luna J, Migliori GB, D’Ambrosio $\mathrm{L}$, Carrillo-Alduenda JL, Villareal-Velarde $\mathrm{H}$, et al. Comparison of bacteriological conversion and treatment outcomes among MDR-TB patients with and without diabetes in Mexico: Preliminary data. Rev Port Pneumol (2006). 2017;23(1):27-30.
27. Bastos ML, Cosme LM, Fregona G, Prado TN, Bertolde Al, Zandonade $E$, et al. Treatment outcomes of MDR-tuberculosis patients in Brazil: a retrospective cohort analysis. BMC Infect Dis. 2017;17(1):718. https://doi.org/10.1186/s12879-017-2810-1

28. Ramalho DMP, Miranda PFC, Andrade MK, Brígido T, Dalcolmo MP Mesquita $E$, et al. Outcomes from patients with presumed drug resistant tuberculosis in five reference centers in Brazil. BMC Infect Dis. 2017; 17(1):571. https://doi.org/10.1186/s12879-017-2669-1

29. Calderón RI, Velásquez GE, Becerra MC, Zhang Z, Contreras CC Yataco RM, et al. Prevalence of pyrazinamide resistance and Wayne assay performance analysis in a tuberculosis cohort in Lima, Peru. Int J Tuberc Lung Dis. 2017;21(8):894-901. https://doi.org/10.5588/ ijtld.16.0850

30. Evora LHRA, Seixas JM, Kritski AL. Neural network models for supporting drug and multidrug resistant tuberculosis screening diagnosis. Neurocomputing. 2017;265:116-126. https://doi. org/10.1016/j.neucom.2016.08.151

31. Sweetland AC, Kritski A, Oquendo MA, Sublette ME, Norcini Pala A Silva LRB, et al. Addressing the tuberculosis-depression syndemic to end the tuberculosis epidemic. Int J Tuberc Lung Dis. 2017;21(8):852 861. https://doi.org/10.5588/ijtld.16.0584

32. David SG, Lovero KL, Pombo March MFB, Abreu TG, Ruffino Netto A, Kritski AL, et al. A comparison of tuberculosis diagnostic systems in a retrospective cohort of HIV-infected children in Rio de Janeiro, Brazil, Int J Infect Dis. 2017;59:150-155. https://doi.org/10.1016/j. ijid.2017.01.038

33. de Almeida IN, de Assis Figueredo LJ, Soares VM, Vater MC, Alves S, da Silva Carvalho W, et al. Evaluation of the Mean Cost and Activity Based Cost in the Diagnosis of Pulmonary Tuberculosis in the Laboratory Routine of a High-Complexity Hospital in Brazil. Front Microbiol. 2017;8:249. https://doi.org/10.3389/fmicb.2017.00249

34. Wysocki AD, Villa TC, Arakawa T, Brunello ME, Vendramini SH Monroe $\mathrm{AA}_{\text {, et }}$ al. Latent Tuberculosis Infection Diagnostic and Treatment Cascade among Contacts in Primary Health Care in a City of Sao Paulo State, Brazil: Cross-Sectional Study. PLoS One. 2016;11(6):e0155348. https://doi.org/10.1371/journal.pone.0155348

35. Langley, I, Squire SB, Dacombe R, Madan J, Lapa e Silva, JR, Galiez, $R$, et al. Developments in Impact Assessment of New Diagnostic Algorithms for Tuberculosis Control. Clin Infect Dis. 2015;61 Supp 3:S126-34. https://doi.org/10.1093/cid/civ580 